\title{
PENGARUH MODEL PEMBELAJARAN CUPS TERHADAP KEMAMPUAN PEMAHAMAN KONSEP SISWA PADA PELAJARAN IPA DI SD
}

\author{
Teofilus Indah Pranata1), Feby Agwadinata1), Emi Sulistri"1), Evinna Cinda Hendriana ${ }^{1)}$ \\ ${ }^{1)}$ Departemen Pendidikan Guru Sekolah Dasar, STKIP Singkawang, Singkawang, Kalimantan Barat, Indonesia \\ Corresponding author: Feby Agwadinata \\ E-mail : febydinata2014@gmail.com
}

Diterima 20 Oktober 2021, Direvisi 29 Oktober 2021, Disetujui 29 Oktober 2021

\begin{abstract}
ABSTRAK
Penelitian ini bertujuan untuk mengetahui pengaruh penerapan model pembelajaran (Conceptual Understanding Prosedures) CUPs terhadap pemahaman konsep siswa pada materi panas dan perpindahannya. Penelitian ini dilaksanakan di SDN 82 Singkawang. Jenis penelitian yang digunakan yaitu kuantitatif dengan metode quasi experimental design (eksperimen semu). Desain penelitian yang digunakan adalah non equivalent pre-test and post-test control group design. Populasi dalam penelitian ini adalah seluruh siswa kelas V SDN 82 Singkawang. Sampel diambil menggunakan teknik purposive sampling, sampel yang terpilih menjadi kelas eksperimen kelas VA yaitu kelas eksperimen yang menggunakan model pembelajaran CUPs dan VB kelas kontrol yang menggunakan model pembelajaran langsung. Hasil penelitian dapat disimpulkan bahwa: (1) Terdapat pengaruh model CUPs terhadap pemahaman konsep siswa pada materi panas dan perpindahannya diperoleh thitung $>$ trabel yaitu 3,4195 > 2,01006 maka $\mathrm{H}_{\mathrm{a}}$ diterima dan $\mathrm{H}^{\circ}$ ditolak. (2) Terdapat peningkatan pemahaman konsep siswa setelah diterapkan model pembelajaran CUPs sebesar 0,76 pada kategori tinggi. (3) Respon siswa tergolong sangat baik terhadap model pembelajaran CUPs.
\end{abstract}

Kata kunci: Model Pembelajaran CUPs; Kemampuan Pemahaman Konsep

\begin{abstract}
This study aims to determine the effect of applying the CUPs learning model (Conceptual Understanding Procedures) on students' conceptual understanding of heat and its transference. This research was conducted at SDN 82 Singkawang. The type of research used is quantitative with a quasi-experimental design method (quasi-experimental). The research design used was a non-equivalent pre-test and posttest control group design. The population in this study were all fifth grade students at SDN 82 Singkawang. The sample was taken using purposive sampling technique, the sample was selected to be the experimental class VA class, namely the experimental class using the CUPs learning model and the control class VB using the direct learning model. The results of the study can be concluded that: (1) There is an effect of the CUPs model on students' understanding of the concept of heat and its transfer, it is obtained that $t$ _count $>\mathrm{t}$ _table is $3.4195>2.01006$ then $\mathrm{H} \_\mathrm{a}$ is accepted and $\mathrm{H} \_\mathrm{O}$ is rejected. (2) There is an increase in students' conceptual understanding after the application of the CUPs learning model of 0.76 in the high category. (3) Students' responses are classified as very good towards the CUPs learning model.
\end{abstract}

Keywords: CUPs Learning Models; The Ability To Understand Concepts. .

\section{PENDAHULUAN}

Pembelajaran IPA memfokuskan pada pemberian pengalaman langsung guna mengembangkan kompetensi pada diri siswa, sehingga siswa yang menemukan dan siswa yang memahami peristiwa alam secara ilmiah (Desliani, 2013). Pembelajaran IPA bukan pembelajaran yang pasif, di mana tingkah laku kelas dan penyebaran pengetahuan dikontrol dan ditentukan oleh guru, sedangkan siswa hanya dipandang sebagai obyek menerima apa yang diberikan guru. Pembelajaran IPA lebih menekankan pada pembelajaran aktif, di mana siswa dipandang sebagai subjek dan objek. Pada proses pembelajaran siswa mempunyai dasar untuk berkembang secara optimal sesuai dengan kemampuan yang dimilikinya. Hal ini dapat dilihat berdasarkan tujuan pembelajaran IPA yang lebih menekankan pada mengembangkan kemampuan siswa.

Tujuan mata pelajaran IPA antara lain: (1) memperoleh keyakinan terhadap Tuhan Yang Maha Esa berdasarkan keberadaan, keindahan dan keteraturan alam ciptaan-Nya; (2) mengembangkan pengetahuan, pemahaman konsep-konsep yang bermanfaat 
diterapkan dalam kehidupan sehari-hari; (3) mengembangkan rasa ingin tahu, sikap kognitif dan kesadaran tentang adanya hubungan saling mempengaruhi antara IPA, lingkungan, teknologi dan masyarakat; (4) mengembangkan keterampilan proses untuk menyelidiki alam sekitar, memecahkan masalah, dan membuat keputusan; (5) meningkatkan kesadaran untuk berperan serta dalam memelihara, menjaga dan melestarikan lingkungan alam; (6) meningkatkan kesadaran untuk menghargai alam dan segala keteraturannya sebagai salah satu ciptaan Tuhan; (7) memperoleh bekal pengetahuan, konsep dan keterampilan IPA sebagai dasar untuk melanjutkan pendidikan ke SMP / MTs (Permendiknas, 2006).

Proses pembelajaran adalah hubungan timbal balik antara guru dan siswa, namun masih banyak ditemukan guru menjadi pusat dalam proses pembelajaran (teacher centered), sedangkan dalam pembelajaran IPA penting dalam meningkatkan kemampuan pengetahuan yang dimilki peserta didik, mampu melakukan kerja ilmiah, serta dengan diiringi sikap ilmiah. Banyak upaya yang dapat dilakukan untuk meningkatkan pembelajaran IPA, salah satunya adalah dengan mengubah pembelajaran yang bersifat teacher centered menjadi student centered. Proses pembelajaran yang seperti ini diharapkan peserta didik akan mampu menemukan sendiri ilmu pengetahuan, serta mempunyai keterampilan proses untuk menyelidiki fenomena yang terjadi di alam sekitarnya, siswa diharapkan mampu memahami IPA secara integrated untuk dapat mengembangkannya dalam kehidupan sehari-hari. Namun kenyataannya, masih jauh diharapkan, karena masih dijumpai banyaknya proses pembelajaran yang tidak sesuai dengan hakikat IPA sehingga peserta didik sering mengalami kesulitan dalam memahami konsep pembelajaran.

Pemahaman konsep diartikan kemampuan siswa mengetahui dan mengambil makna dari materi yang sedang dipelajari dimana pemahaman konsep itu bukan hanya memenuhi aspek mengingat saja melainkan paham akan konsep tersebut dan melekat dalam pikiran siswa biarpun materi tersebut telah dipelajari (Utami Dkk, 2015). Menurut (Dede, 2018) Pemahaman konsep berarti siswa tidak hanya sebatas mengetahui konsepnya saja tetapi siswa juga mampu menjelaskan kembali materi yang diajarkan dengan kalimat sendiri serta dapat menerapkannya dalam kehidupan sehari-hari. Pemahaman konsep IPA merupakan proses pemaparan suatu fakta atau konsep IPA secara rinci, melalui pengamatan dan percobaan (Rahma, 2018). Kategori pemahaman konsep meliputi menafsirkan, mencontohkan, mengklasifikasikan, meringkas, menyimpulkan, membandingkan dan menjelaskan. Melalui kemampuan tersebut akan membantu siswa menangkap dan mengungkapkan makna suatu pengetahuan (konsep) (Suhendi, 2014).

Berdasarkan dari hasil prariset di SDN 82 Singkawang, terdapat tiga indikator pemahaman konsep berbentuk soal pilihan ganda yang di teskan kepada siswa kelas $\mathrm{V}$ berjumlah 25 siswa yang memiliki pemahaman konsep yang bervariasi. Siswa yang dapat mencontohkan dari 25 siswa hanya 11 siswa yang menjawab benar (44\%), siswa yang dapat menafsirkan dan mengklasifikas berjumlah 8 orang (32\%). Hal ini di perkuat dari hasil kegiatan wawancara dengan guru kelas,yang menyatakan bahwa siswa kurang dalam hal memahami sebuah konsep, sehingga ketika diberi soal ulangan maupun soal latihan yang berhubungan dengan pemahaman konsep tidak banyak dari siswa yang mendapatkan nilai yang sesuai dengan KKM kriteria kentuntasan minimal yang telah ditetapkan dalam pembelajaran IPA yaitu 70. Guru kelas juga menyatakan bahwa siswa kurang fokus selama proses belajar mengajar berlangsung. Selain itu, ketika guru menyampaikan materi terdapat beberapa siswa yang berbicara dengan teman sebelahnya dan ada yang mengerjakan tugas lain. Saat melakukan wawancara dengan siswa, siswa menyatakan bahwa pembelajaran yang berlangsung di dalam kelas hanya terpusat pada guru dan siswa tidak diterapkan belajar dalam bentuk kelompok. Siswa juga menyatakan saat proses pembelajaran dimulai dimana guru sedang menjelaskan pembelajaran dan memberi latihan soal tidak banyak dari mereka hanya fokus pada diri sendiri dan teman sebangkunya. Adapun yang dilakukan guru adalah guru memberikan latihan soal, penugasan, dan guru dalam menyampaikan materi cenderung kurang memberikan pengalaman langsung pada siswa contohnya merupakan pengamatan ataupun percobaan. Selain itu siswa dibiasakan memecahkan masalah dalam bentuk matematis dan tentunya ini membuat siswa kesulitan dalam pemahaman konsep IPA.

Berdasarkan permasalahan tersebut salah satu model pembelajaran yang dapat meningkatkan pemahaman konsep siswa adalah model pembelajaran CUPs (Conceptual Understanding Prosedures). CUPs merupakan pembelajaran kooperatif yang artinya mengerjakan sesuatu secara berkelompok dengan saling membantu satu sama lainnya sebagai satu tim (Yani, 2013). Belajar 
bergotong-royong, dan setiap anggota kelompok/tim saling membantu merupakan inti dari model pembelajaran ini (Anggraeni, 2011). Adapun tahapan Model pembelajaran CUPs yaitu, fase individu, fase kelompok dan fase presentasi (Ismawati, 2014). Salah satu materi IPA yang sulit siswa pahami yaitu materi panas dan perpindahannya.

Menurut Penelitian (Faury, 2019) Hasil penelitiannya menunjukkan bahwa terdapat pengaruh model pembelajaran CUPs terhadap pemahaman konsep siswa dibandingkan dengan model pembelajaran konvensional. Selain itu penelitian menurut (Ismawati, 2014) menyatakan bahwa hasil Peningkatan pemahaman konsep pada kedua kelas termasuk dalam kategori sedang. Dapat disimpulkan bahwa model pembelajaran CUPs terbukti dapat meningkatkan pemahaman konsep siswa pada materi pemuaian.

\section{METODE PENELITIAN}

Metode quasi experimental design (eksperimen semu). Menurut (Sugiyono, 2015) penelitian eksperimen semu adalah suatu cara untuk digunakan karena pada kenyataannya sulit mendapatkan kelompok kontrol yang digunakan dalam penelitian. Model ini dipakai untuk menguji hipotesis berbentuk hubungan sebab akibat melalui perlakuan dan menguji perubahan yang diakibatkan oleh perlakuan tersebut. Peneliti meneliti ada tidaknya pengaruh penerapan model pembelajaran CUPs terhadap pemahaman konsep siswa yang terdapat dalam kelas eksperimen. Kelas eksperimen adalah kelas dengan perlakuan model CUPs dan kelas kontrol dengan model pembelajaran konvensional (model yang biasa dilakukan oleh guru). Perbedaan pemahaman pada kedua kelompok perlakuan dapat dilihat dengan melakukan pretest sebelum pembelajaran dimulai, tujuannya untuk mengatahui sejauh mana pengetahuan awal siswa tentang materi yang akan diberikan. Kemudian dilakukan posttest setelah pembelajaran berakhir, tujuannya untuk mengetahui perubahan hasil belajar siswa kelas $\mathrm{V}$ setelah pembelajaran menggunakan model pembalajaran CUPs.

Pada penelitian ini, peneliti menggunakan non equivalent pre-test and posttest control group design. Dalam desain ini terdapat dua sampel yaitu kelas eksperimen dan kelas kontrol tidak dipilih secara random. Dimana sampel dalam penelitian ini diberi perlakuan (treatment) selama waktu tertentu. Pre-test dilaksanakan sebelum pemberian treatment, dan post-test dilaksanakan setelah treatment. Populasi dalam penelitian ini adalah seluruh siswa kelas V di SDN 82 Singkawang yang terdiri dari dua kelas yaitu VA dan VB. Sampel adalah bagian dari jumlah dan karakteristik yang dimiliki oleh populasi (Sugiyono, 2015). Teknik pengambilan sampel dalam penelitian ini adalah purposive sampling, yaitu teknik penentuan Sampel dengan pertimbangan tertentu (Sugiyono, 2015). Pertimbangan yang diambil pada penelitian ini adalah kelas yang ada mempelajari materi pelajaran panas dan perpindahannya yang terdapat pada kelas V SD. Kelas yang yang akan dijadikan sampel yaitu kelas V. Dimana kelas $\mathrm{V}$ terdapat 2 kelas yaitu kelas VA, dan VB. Setelah pengambilan sampel kelas yang terpilih sebagai kelas eksperimen dalam penelitian ini adalah kelas VA yang berjumlah 25 siswa, sedangkan kelas yang terpilih sebagai kelas kontrol adalah kelas VB dengan jumlah 25 siswa. Jumlah populasi dan sampel didapat dari data sekolah yang dimana kelas $\mathrm{V}$ terdiri dari 2 kelas dan setiap kelas terdiri dari 25 orang.

Teknik pengumpulan data yang digunakan pada penelitian ini adalah teknik tes dan non tes. Tes yang digunakan adalah tes diagnostik berbentuk pilihan ganda mengenai materi Panas dan Perpindahannya. Tes ini diberikan pada dua kelas sampel yaitu kelas eksperimen dan kelas kontrol. Tes di kelas eksperimen dilaksanakan sebelum dan sesudah model pembelajaran CUPs (Conceptual Understanding Prosedures) dilaksanakan. Non tes yang digunakan berupa lembar respon siswa. Pengumpulan data lembar respon siswa ketika model pembelajaran telah diterapkan

\section{HASIL DAN PEMBAHASAN \\ HASIL PENELITIAN \\ Kemampuan pemahaman konsep siswa}

Penelitian ini bertujuan untuk mengetahui adanya pengaruh model pembelajaran Conceptual Understanding Procedure (CUPs) terhadap kemampuan pemahaman konsep siswa pada materi Panas dan Perpindahannya. Penerapan model pembelajaran (CUPs) dilakukan sebanyak 2 pertemuan (4 X 40 menit). Kegiatan pembelajaran dilaksanakan di dalam kelas dengan peneliti bertindak sebagai guru. Sebelum model pembelajaran CUPS dilaksanakan, sampel penelitian diberikan pretest untuk mengetahui pemahaman siswa menggunakan soal pilihan ganda yang terdiri dari 10 soal dengan memuat 6 indikator pemahaman konsep yaitu : (1) Menafsirkan (2) Mencontohkan (3) Mengklasifikasikan (4) Menyimpulkan (5) Membandingkan (6) Menjelaskan. Tahapan pembelajaran dalam penelitian ini terdiri dari tiga tahapan. Tahap pertama siswa bekerja secara individu. Tahap 
kedua adalah siswa bekerja secara kelompok dimana siswa dibagi menjadi kelompok kecil untuk melakukan demonstrasi dan menjawab soal yang telah di siapkan oleh guru. Tahap ketiga diskusi kelas pada tahap ini siswa mendiskusikan jawaban soal yang telah di siapkan oleh guru dengan menpersentasikan jawaban soal ke depan kelas. Setelah data dianalisis, maka diperoleh nilai rata-rata, standar deviasi, varians dan jumlah siswa kelas eksperimen dan kelas kontrol. Untuk selengkapnya disajikan nilai pada Tabel 1

Tabel 1. Rekapitulasi Nilai Post-Test Siswa

Kelas Eksperimen dan Kontrol

\begin{tabular}{ccccc}
\hline Kelas & $\begin{array}{c}\text { Rata- } \\
\text { rata }(\end{array}$ & $\begin{array}{c}\text { St. } \\
\text { Deviasi } \\
(\mathrm{SD})\end{array}$ & $\begin{array}{c}\text { Varians } \\
\left(\mathrm{S}^{2}\right)\end{array}$ & $\begin{array}{c}\text { Jumlah } \\
\text { siswa } \\
(\mathrm{n})\end{array}$ \\
\hline Kontrol & 52 & 19,51 & 380,66 & 25 \\
\hline Eksperimen & 76 & 16,07 & 258,33 & 25 \\
\hline
\end{tabular}

Berdasarkan tabel 1. di atas, terdapat perbedaan rata-rata untuk kemampuan pemahaman konsep siswa antara kelas eksperimen dengan kelas kontrol dimana ratarata skor kelas eksperimen terdapat nilai 76 , rata-rata skor kelas kontrol terdapat nilai 52. Hal ini menunjukkan bahwa adanya peningkatan pemahaman konsep setelah siswa diberikan treatmen dengan model CUPs. Berdasarkan aspek pemahaman konsep siswa data peningkatan setiap aspek berkatagori sedang. Adapun hasil peningkatan aspek pemahaman konsep dapat dilihat pada Tabel 2.

Tabel 2. Peningkatan Aspek Pemahaman Konsep

\begin{tabular}{cccccc}
\hline $\begin{array}{c}\text { Aspek } \\
\begin{array}{c}\text { Pemahaman } \\
\text { Konsep }\end{array}\end{array}$ & $\begin{array}{c}\text { Skor } \\
\text { Maks }\end{array}$ & $\begin{array}{c}\text { Skor } \\
\text { Pre } \\
\text { Test }\end{array}$ & $\begin{array}{c}\text { Skor } \\
\text { Post } \\
\text { Test }\end{array}$ & $\begin{array}{c}\text { n- } \\
\text { gain }\end{array}$ & Kategori \\
\hline Menafsirkan & 50 & 19 & 34 & 0,48 & Sedang \\
\hline Mencontohkan & 25 & 12 & 18 & 0,46 & Sedang \\
\hline Mengklasifikasi & 75 & 51 & 62 & 0,45 & Sedang \\
\hline Menyimpulkan & 25 & 17 & 20 & 0,37 & Sedang \\
\hline Membandingkan & 25 & 17 & 20 & 0,37 & Sedang \\
\hline Menjelaskan & 50 & 18 & 34 & 0,50 Sedang \\
\hline
\end{tabular}

Peningkatan aspek pemahaman konsep disajikan dalam bentuk diagram batang pada Gambar 1.

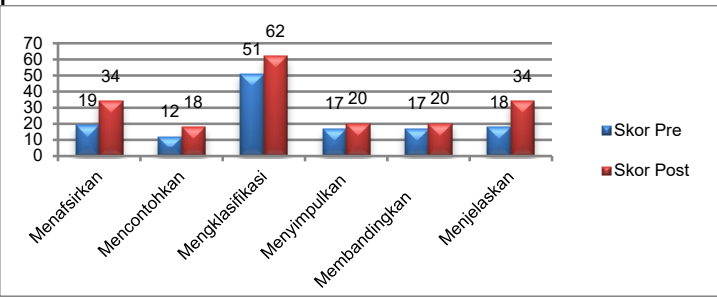

Gambar 1. Diagram Batang Peningkatan Skor Pre-Test dan Post-Test

Berdasarkan data Gambar 1, terdapat Jumlah skor maksimal aspek pemahaman yang diukur berbeda-beda meyesuaikan dengan banyaknya soal di aspek tersebut. Pada aspek menafsirkan terjadi peningkatan skor pre-test ke post-test sebanyak 15 poin, aspek mencontohkan terjadi peningkatan sebanyak 6 poin, aspek mengklarifikasi terjadi peningkatan sebanyak 11 poin, aspek menyimpulkan terjadi peningkatan sebanyak 3 poin, aspek membandingkan terjadi peningkatan sebanyak 3 poin, dan aspek menjelaskan terjadi peningkatan sebanyak 16 poin.

\section{Analisis Pengaruh Model Pembelajaran CUPs}

Untuk mengetahui perbedaan kemampuan pemahaman konsep siswa antara kelas eskperimen dan kelas kontrol pada materi panas dan perpindahannya kelas $\mathrm{V}$ menggunakan uji $t$ dua sampel. Namun sebelumnya akan dilakukan uji normalitas dan homogenitas terlebih dahulu. Adapun uji normalitas dan homogenitas sebagai berikut.

\section{1) Uji normalitas}

Uji normalitas yang dilakukan dalam penelitian ini untuk menentukan skor data posttest yang telah dikumpulkan berdistribusi normal atau tidak. Hasil analisis uji normalitas data post-test kemampuan pemahaman konsep siswa kelas eksperimen dan kelas kontrol dapat dilihat pada tabel 3 .

Tabel 3. Hasil Perhitungan Uji Normalitas Data

\begin{tabular}{|c|c|c|}
\hline \multirow[b]{2}{*}{ Statistika } & \multicolumn{2}{|l|}{ Kelas } \\
\hline & Eksperimen & Kontrol \\
\hline $\mathrm{X}^{2}$ hitung & $-22,4219$ & $-13,9379$ \\
\hline Jumlah siswa (n) & 25 & 25 \\
\hline Taraf kesukaran $(\alpha)$ & $5 \%$ & $5 \%$ \\
\hline $\mathrm{X}^{2}$ tabel & 7,81472 & 7,81472 \\
\hline
\end{tabular}

Dari tabel 3. terlihat bahwa hasil perhitungan uji normalitas data pada kelas eksperimen $x^{2}$ hitung $\leq x^{2}$ tabel yaitu $-22,4219 \leq$ 7,81472 maka data dikatakan berdistribusi normal. Sedangkan hasil perhitungan uji normalitas data pada kelas kontrol didapatkan $x^{2}$ hitung $\leq x^{2}$ tabel sebesar $-13,9379 \leq 7,81472$ maka data berdistribusi normal. Karena data kelas eksperimen dan kelas kontrol berdistribusi normal, maka untuk menentukan homogenitas data menggunakan rumus $f$.

\section{2) Uji homogenitas data menggunakan rumus $f$}

Setelah data skor post-test kelas eksperimen dan kelas kontrol dihitung dan didapatkan data tersebut berdistribusi normal, selanjutnya akan melakukan uji homogenitas data menggunakan rumus f. Adapun hasil perhitungan uji homogenitas pada tabel 4 .

Tabel 4. Hasil Perhitungan Uji Homogenitas

\begin{tabular}{lcc}
\hline \multirow{2}{*}{ Statistik } & \multicolumn{2}{c}{ Kelas } \\
\cline { 2 - 3 } & Eksperimen & Kontrol \\
\hline Varians $\left(s^{2}\right)$ & 380,7 & 258,3 \\
\hline $\begin{array}{l}\text { Jumlah siswa } \\
\text { (n) }\end{array}$ & 25 & 25 \\
\hline
\end{tabular}




\begin{tabular}{ccc}
\hline $\begin{array}{l}\text { Taraf } \\
\text { kesukaran }(\alpha)\end{array}$ & $5 \%$ & $5 \%$ \\
\hline$f_{\text {hitung }}$ & 1,47 & \\
\hline$f_{\text {tabel }}$ & 1,98 & \\
\hline
\end{tabular}

Berdasarkan Tabel 4 di atas, terlihat bahwa perhitungan data menggunakan rumus $\mathrm{f}$. Diketahui varians kelas eksperimen yaitu 380,7 sedangkan varinas kelas kontrol adalah 258,3 sehingga $f_{\text {hitung }}$ adalah 1,47 . Dari $f$ tabel dengan $\mathrm{a}=5 \%$ dan dk pembilang 24 dan dk penyebut 24 diperoleh $f_{\text {tabel }}=1,98$. Karena $f_{\text {hitung }}<f_{\text {tabel }}$ yaitu 1,47 <1,98 maka kelas eksperimen dan kelas kontrol mempunyai varians yang sama atau homogen. Karena data nilai pada kelas eksperimen dan kontrol berdistribusi normal dan homogen, maka selanjutnya dilakukan uji t dua sampel untuk mengetahui apakah terdapat pengaruh kemampuan pemahaman konsep siswa antara kelas yang diberikan model pembelajaran CUPs dengan kelas yang diberikan pembelajaran langsung pada materi panas dan perpindahannya.

\section{3) Uji perbedaan kelas eksperimen dan kontrol menggunakan uji t dua sampel}

Berdasarkan uji normalitas dan homogenitas diperoleh bahwa data post-test kelas eksperimen maupun kelas kontrol berdistribusi normal dan mempunyai varians yang sama atau homogen. Maka untuk menguji kesamaan rata-rata kedua kelas menggunakan uji t dua sampel. Berikut hasil perhitungan uji t dua sampel dapat dilihat pada tabel 5 .

Tabel 5. Hasil Perhitungan Uji T Dua Sampel

\begin{tabular}{|c|c|c|c|c|c|c|}
\hline $\begin{array}{l}\text { Kelomp } \\
\text { ok }\end{array}$ & $\begin{array}{l}D \\
k\end{array}$ & $\alpha$ & $t_{\text {hitung }}$ & $\mathrm{T}_{\text {tabel }}$ & $\begin{array}{l}\text { Kepu } \\
\text { tusan }\end{array}$ & $\begin{array}{l}\text { Kesimpul } \\
\text { an }\end{array}$ \\
\hline $\begin{array}{l}\text { Kelas } \\
\text { Eksperi } \\
\text { men } \\
\text { dan } \\
\text { Kontrol }\end{array}$ & $\begin{array}{l}4 \\
8\end{array}$ & $\begin{array}{l}5 \\
\%\end{array}$ & 3,4195 & $\begin{array}{l}2,01 \\
006\end{array}$ & $\begin{array}{l}\mathrm{H}_{\mathrm{a}} \\
\text { diteri } \\
\text { ma }\end{array}$ & $\begin{array}{l}\text { Terdapat } \\
\text { perbedaa } \\
\mathrm{n} \\
\text { kemamp } \\
\text { uan }\end{array}$ \\
\hline
\end{tabular}

Berdasarkan Tabel 5. Thitung $=3,4195$ dan $t_{\text {tabel }}=2,01006$ diperoleh $t_{\text {hitung }}>t_{\text {tabel }}$ yaitu 3,4195 > 2,01006 maka $\mathrm{H}_{\mathrm{a}}$ diterima dan $\mathrm{H}^{\circ}$ ditolak. Sehingga dapat disimpulkan bahwa terdapat perbedaan kemampuan pemahaman konsep siswa antara kelas yang diberikan model pembelajaran CUPs dengan pembelajaran langsung pada materi panas dan perpindahannya. Karena terdapat perbedaan maka ada pengaruh kemampuan pemahaman konsep siswa antara kelas yang diberikan model pembelajaran CUPs dengan pembelajaran langsung pada materi panas dan perpindahannya.
Analisis Peningkatan pemahaman konsep setelah diterapkan Model Pembelajaran CUPs

Setelah mendapat data pre-test dan post-test dari kelas eksperimen, data kemudian dianalisis menggunakan uji $\mathrm{N}$-gain. Penggunaan uji $\mathrm{N}$-gain bertujuan untuk mendeskripsikan peningkatan keterampilan proses sains siswa setelah diterapkan model pembelajaran CUPs. Peningkatan setiap aspek dalam pemahaman konsep dianalisis menggunakan uji $N$-gain. Pada aspek menafsirkan terjadi peningkatan sebesar 0,48 dengan kategori sedang, aspek mencontohkan meningkat sebesar 0,46 dengan katagori sedang, sedangkan mengklarifikasi terjadi peningkatan pemahaman konsep sebesar 0,45 dengan katagori sedang, aspek menyimpulkan dan aspek membandingkan meningkat sebesar 0,37 dalam katagori sedang, dan aspek menjelaskan meningkat sebesar 0,5 dalam katagori sedang. Adapaun peningkatan uji $\mathrm{N}$ gain setiap aspek pemahaman konsep dapat dilihat pada Gambar 2.

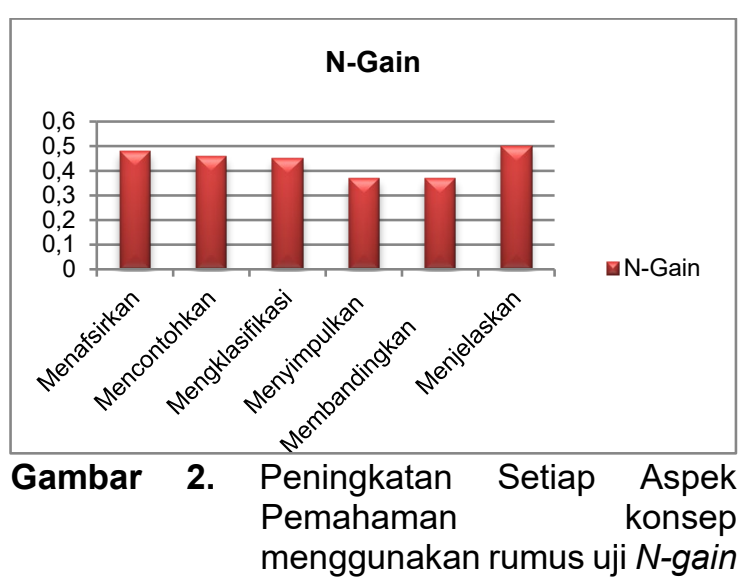

Berdasarkan perhitungan tersebut terlihat bahwa skor rata-rata tes pemahaman konsep siswa setelah dinormalisasi diperoleh peningkatan nilai sebesar 0,76 dengan kategori tinggi.

\section{Angket Respon Siswa}

Respon siswa terhadap model pembelajaran CUPs pada materi panas dan perpindahannya diperoleh melalui lembar angket respon siswa yang diberikan kepada seluruh siswa kelas eksperimen yang berjumlah 25 siswa. Data yang disajikan berupa tanggapan terhadap pernyataan-pernyataan yang terdapat pada angket respon siswa. Hasil perhitungan respon siswa bisa di lihat pada tabel 6 . 
Tabel 6. Hasil Perhitungan Respon Siswa

\begin{tabular}{|c|c|c|}
\hline \multirow[t]{2}{*}{ Aspek } & \multicolumn{2}{|c|}{$\begin{array}{c}\text { Persentase } \\
\text { Tanggapan Siswa } \\
(\%)\end{array}$} \\
\hline & $\mathrm{S}$ & TS \\
\hline $\begin{array}{l}\text { Semangat dalam mengikuti } \\
\text { pembelajaran }\end{array}$ & 89 & 11 \\
\hline Penggunaan Media & 84 & 16 \\
\hline $\begin{array}{l}\text { Ketertarikan dalam } \\
\text { mempelajarari IPA }\end{array}$ & 84 & 16 \\
\hline $\begin{array}{l}\text { Memudahkan memahami } \\
\text { konsep IPA }\end{array}$ & 72 & 28 \\
\hline Bekerjasama dalam kelompok & 84 & 16 \\
\hline Rata-rata & \multicolumn{2}{|c|}{$83 \%$} \\
\hline
\end{tabular}

Berdasarkan tabel 6, respon siswa terhadap model pembelajaran CUPs diperoleh bahwa $89 \%$ siswa semangat dalam mengikuti pembelajaran, siswa menyatakan media sangat membantu dalam pembelajaran sebesar $84 \%$, siswa juga menjadi tertarik dalam pembelajaran IPA sebesar $84 \%$, sebesar $72 \%$ siswa menyatakan dengan menggunakan model CUPs ini lebih mudah memahami konsep IPA, dan $84 \%$ siswa mampu bekerja sama dalam pembelajaran.

\section{PEMBAHASAN PENELITIAN \\ Pengaruh Model CUPs Terhadap Peningkatan Pemahaman Konsep Siswa \\ Peneliti melakukan penelitian di}

Sekolah Negeri Singkawang yang terdiri dari 2 kelas yaitu kelas VA dan kelas VB. Kelas eksperimen berasal dari kelas VA yang terdiri dari 25 siswa, sedangkan kelas kontrol berasal dari kelas VB yang terdiri dari 25 siswa juga. Untuk kelas eksperimen diberikan model pembelajaran CUPs sedangkan kelas kontrol diberikan model pembelajaran langsung. Tahap pertama pada model pembelajaran CUPs (Conceptual Understanding Prosedures) yaitu fase individu, dalam tahap ini guru mengecek kehadiran siswa, dan mengingatkan kembali materi yang sudah dipelajari, siswa mengamati gambar yang ditampilakn oleh guru, siswa mengisi soal yang terdapat di LKS berhubungan dengan gambar yang ditampilan oleh guru. Pemberian soal tersebut dapat melatihkan pemahaman konsep siswa, menafsirkan, mencontohkan, mengklasifikasi, menyimpulkan, membandingkan, dan menjelaskan. Melalui tampilan gambar siswa dituntut untuk lebih fokus dalam suatu pengamatan yang ditampilkan guru sehingga siswa dapat menjawab soal yang diberikan oleh guru,

Pada tahap kedua model pembelajaran pembelajaran CUPs (Conceptual Understanding Prosedures) yaitu fase kelompok, Guru membagi siswa menjadi beberapa kelompok kecil, memberikan LKS (lembar kerja siswa) dan alat unruk melakukan praktikum serta guru mengarahkan siswa untuk melakukan kegiatan praktikum. Kemudian siswa diminta untuk mengisi soal yang terdapat di dalam LKS sehingga hal tersebut dapat melatih pemahaman konsep siswa. Melalui kerja kelompok siswa dapat bertukar pikiran dengan temannya sehingga memotivasi siswa untuk memecahkan suatu masalah dapat dilakukan secara bekerja sama dalam satu kelompok. Kerja kelompok membuat siswa menimbulkan rasa keinginan untuk membantu siswa lainnya dalam kelompok yang mengalami kesulitan, sehingga membuat siswa menjadi semangat untuk mengembangkan kemampuan pemahamannya (Siregar, 2016). Hal ini diperkuat oleh (Suryanti, 2017) kerja kelompok membuat siswa timbul rasa keinginan untuk bertukar pikiran di setiap permasalahan dan melatih siswa dalam mengungkapkan suatu pendapat, sehingga membuat peserta didik menjadi semangat dalam memahami pembelajaran.

$$
\text { Tahap terakhir pada model }
$$

pembelajaran CUPs (Conceptual Understanding Prosedures) yaitu fase diskusi, guru mengarahkan siswa untuk berdiskusi yang terdapat pada LKS, mengarahkan setiap salah satu anggota kelompok siswa untuk presentasi ke depan kelas dan memberikan kesempatan kepada kelompok lain untuk mengomentari atau bertanya kepada kelompok yang presentasi. Dengan berdiskusi dapat melatih pemahaman konsep siswa pada aspek menafsirkan, mencontohkan, mengklasifikasi, menyimpulkan, membandingkan, dan menjelaskan.

Skor posttest antara kelas eksperimen dan kelas kontrol memperoleh nilai yang berbeda. Kelas eksperimen mendapatkan skor yang lebih tinggi dari kelas kontrol $\mathrm{Hal}$ ini dikarenakan pada kelas eksperimen peningkatan rata-rata skor keseluruhan aspek pemahaman konsep siswa dalam kategori tinggi. Selanjutnya pada kelas kontrol peningkatan rata-rata skor keseluruhan aspek pemahaman konsep siswa dalam kategori sedang. Sehingga dengan model pembelajaran Cups yang diterapkan pada kelas eksperimen dapat mempengaruhi kemampuan pemahaman siswa.

Perhitungan data post-test siswa didapatkan thitung $>$ tabel sehingga terdapat pengaruh peningkatan kemampuan pemahaman konsep siswa di kelas yang diberikan model pembelajaran CUPs dengan pembelajaran langsung pada materi panas dan perpindahannya. Sehingga dapat disimpulkan bahwa terdapat pengaruh kemampuan pemahaman konsep siswa antara kelas yang diberikan model pembelajaran CUPs dengan 
pembelajaran langsung pada materi panas dan perpindahannya. Hal ini diperkuat dengan hasil penelitian (Safitri, 2020) menunjukkan berdasarkan uji-t , thitung $>\mathrm{t}$ (tabel) sehingga dapat disimpulkan bahwa peningkatan kemampuan pemahaman konsep matematis siswa yang diajarkan dengan model CUPs lebih baik daripada siswa yang diajarkan dengan model pembelajaran langsung.

\section{Peningkatan Pemahaman Konsep Siswa}

Dari penelitian yang telah dilakukan menggunakan analisis N-gain, dikatakan bahwa kemampuan pemahaman konsep siswa setelah diterapkan model pembelajaran CUPs pada kelas eksperimen mengalami peningkatan lebih baik dari kelas kontrol dengan pembelajaran langsung. Didapatkan bahwa skor rata-rata kemampuan pemahaman konsep siswa sebesar 0,76 dengan kategori tinggi. Hasil di perkuat oleh (Ismawati, 2014) penelitiannya menunjukkan peningkatan pemahaman konsep pada kelas eksperimen diperoleh sebesar 0,67 dapat disimpulkan bahwa model pembelajaran CUPs terbukti lebih efektif untuk meningkatkan pemahaman konsep siswa.

Aspek yang memiliki peningkatan paling tinggi yaitu menjelaskan dimana nilai $\mathrm{N}$ gain nya sebesar 0,50 dengan kategori sedang. Selama proses pembelajaran siswa diberikan pertanyaan-pertanyaan yang merangsang siswa untuk memahami materi yang telah diberikan dan siswa juga diberikan kesempatan untuk menjelaskan apa yang terjadi dari fenomena yang diberikan pada saat siswa mengamati suatu gambar demonstrasi yang diberikan pada tahap pertama fase individu. Menurut (Rizkianingsih, 2012) melalui kegiatan bertanya dan menjawab pertanyaan, siswa dilatih untuk berpikir dalam memahami konsep yang diberikan.

Aspek yang memiliki peningkatan paling rendah yaitu menyimpulkan dan membandingkan sebesar 0,37 dalam kategori sedang. Dalam pembelajaran siswa masih kurang dalam membandingkan contoh perpindahan panas dan masih kurang dalam membuat kesimpulan dari sebuah pembelajaran. Menurut (Rusmianto, 2012) siswa dalam menyimpulkan suatu materi pelajaran masih rendah.

\section{Respon Siswa Setelah Diterapkan Model Pembelajaran CUPs}

Respon siswa terhadap pembelajaran dengan menggunakan model pembelajaran CUPs menunjukkan tanggapan katagori sangat baik. Berdasarkan hasil persentase respon siswa setelah diterapkan model pembelajaran
CUPs dari data pengisian lembar respon siswa. Siswa sangat senang mengikuti pembelajaran IPA dengan menggunakan model pembelajaran CUPs, hal ini ditunjukkan respon siswa yang diperoleh sebesar $96 \%$ dalam kategori sangat baik terhadap materi pelajaran, pengamatan suatu percobaan,melakukan percobaan pemberian LKS, cara guru mengajar, dan tahapan-tahapan yang diarahkan guru dalam proses pembelajaran. Pernyataan respon siswa terdapat 10 pernyataan yang memiliki dua tanggapan yaitu setuju dan tidak setuju yang akan dipilih siswa sesuai pernahaman yang telah dimilikinya selama proses pembelajaran berlangsung. Hal ini didukung dengan penelitian yang dilakukan oleh (Ismawati, 2014) bahwa siswa memberikan respon positif setelah mendapat pembelajaran CUPs.

Pada aspek semangat dalam mengikuti pelajaran termasuk dalam kategori baik sekali sebesar $89 \%$ siswa menyatakan sangat senang mengikuti pembelajaran dengan menggunakan model pembelajaran CUPs dan model pemebelajaran CUPs membuat siswa tidak bosan dalam belajar serta siswa merasa lebh tertarik dalam belajar. Sehingga hal ini dapat menimbulkan pembelajaran yang baik serta membuat pemahaman siswa menjadi lebih baik. Pada aspek penggunaan media termasuk dalam kategori baik sekali sebesar $84 \%$ siswa menyatakan mereka suka dengan model pembelajaran CUPs karena pada model pembelajaran ini siswa terbantu dengan adanya media gambar maupum video dalam memahami sebuah konsep yang diberikan. Pada aspek ketertarikan dalam pembelajaran ipa termasuk kategori sangat baik sebesar $84 \%$ Dikarenakan selama proses pembelajaran siswa dilatih untuk menafsirkan suatu permasalahan yang ada sehingga siswa lebih mudah menerapkan pembelajaran IPA dalam kehidupan sehari-hari. Pada aspek memudahkan memahami konsep IPA termasuk dalam kategori baik yaitu sebesar $72 \%$ siswa menyatakan bahwa menggunakan model pembelajaran CUPs membuat dirinya lebih memahami konsep IPA dengan baik di bandingkan dengan menggunakan model pembelajaran ceramah. Siswa juga lebih paham karena disetiap tahap siswa dilibatkan langsung dalam pembelajaran serta adanya sebuah eksperimen yang menumbuhkan semangat siswa semangkin besar untuk belajar sehingga dengan tidak disadari siswa pun semangkin memahami pembelajaran IPA yang telah di pelajari. Pada aspek dalam berkelompok termasuk dalam kategori sangat baik sebesar $84 \%$ siswa sangat menikmati kebersamaan dalam pembelajaran sehingga siswa mampu untuk bekerjasama dengan 
kelompok dan saling menghargai pendapat siswa yang lain untuk menyelesaikan tugas yang telah diberikan.

\section{SIMPULAN DAN SARAN Simpulan}

Berdasarkan hasil perhitungan data penelitian dan pembahasan secara umum dapat disimpulkan bahwa model pembelajaran CUPs memiliki pengaruh terhadap kemampuan pemahaman konsep siswa pada materi panas dan perpindahannya. Sesuai dengan sub-sub rumusan masalah penelitian, maka secara khusus disimpulkan sebagai berikut:

1. Terdapat pengaruh model CUPs terhadap pemahaman konsep siswa pada materi panas dan perpindahannya. Berdasarkan dari tahap proses pembelajaran yang terdapat pada model pembelajaran CUPs mengakibatkan siswa menjadi aktif. Sehingga model pembelajaran CUPs dapat mempengaruhi kemampuan pemahaman konsep siswa.

2. Terdapat peningkatan pemahaman konsep siswa setelah diterapkan model pembelajaran CUPs. Pada model pembelajaran CUPs memiliki tahap-tahap pembelajaran yang memberikan kesempatan siswa untuk mengutarakan pendapat, melakukan pengamatan, melakukan percobaan, menyimpulkan hal telah diamatinya, dan membuktikan kebenaran suatu konsep melalui percobaan, serta saling bertukar pikiran dengan berdiskusi dan dapat menjelaskan hasil diskusi melalui presentasi.

3. Respon siswa tergolong sangat baik terhadap model pembelajaran CUPs. Pada proses pembelajaran siswa merasa senang dengan menggunakan model CUPs karena pada tahapan CUPs siswa lebih banyak diberikan kesempatan untuk mengutarakan pendapat, siswa lebih aktif dalam belajar, siswa melakukan percobaan serta siswa dapat berinteraksi dengan teman kelasnya.

\section{Saran}

Berdasarkan hasil penelitian yang telah didapatkan, maka saran dalam penelitian ini sebagai berikut: (1). Pelaksanaan model pembelajaran CUPs membutuhkan waktu yang cukup banyak. Jadi, untuk waktu dalam kegiatan pembelajaran seharusnya direncanakan lebih baik lagi, (2). Bagi peneliti yang berminat untuk melakukan penelitian dengan menggunakan model CUPs disarankan untuk memperhatikan ketersediaan alat dan bahan di sekolah, dan penggunaan Lembar Kerja Siswa (LKS), (3). Alat dan bahan yang digunakan untuk praktikum sebaiknya alat dan bahan yang mudah di dapat dan terjangkau sehingga tidak menyulitkan dari prasarana maupun dana, (4). Dalam bekerja sama dan saling bertukar pikiran hendaknya harus di kontrol agar tugas yang di berikan dapat terselesaikan dengan tepat waktu.

\section{UCAPAN TERIMAKASIH}

Ucapan terimakasih disampaikan kepada Kepala Sekolah, guru, dan siswa kelas $\checkmark$ di SDN 82 Singkawang sehingga penelitian ini dapat dilakukan dengan baik. Kemudian ucapan terimakasih juga disampaikan kepada STKIP Singkawang yang telah memfasilitasi peneliti dalam menyelesaikan artikel ini.

\section{DAFTAR RUJUKAN}

Desliani, A. 2013. "Penerapan Model Children Learning in Scince (CLIS) Untuk Meningkatkan Penguasaan Konsep IPA."

Anggraeni, D. 2011. "Peningkatan Kualitas Pembelajaran IPS Melalui Model Pembelajaran Kooperatif Tipe Course Review Horay Pada Siswa Kelas 4 SD Negeri Sekaran 01 Semarang." Pendidikan Dasar 1.

Dede Salim Hadi, DKK. 2018. "Upaya Meningkatkan Pemahaman Konsep Siswa Melalui Penerapan Metode Demonstrasi Pada Mata Pelajaran IPA." Cakrawala Pendasa 4.

Dkk, Utami. 2015. "Model Pembelajaran Children Learning in Science (CLIS) Dalam Pembentukan Konsep Fisika Siswa SMA Di Kabupaten Jember." Artikel IIMIAH Mahasiswa.

Faury, Hidayati. 2019. "Pengaruh Model Pembelajaran Conceptual Understanding Procedures (CUPs) Terhadap Pemahaman Konsep Siswa Pada Materi Pokok Listrik Dinamis." Pendidikan Fisika Program Pascasarjana UNIMED.

Ismawati. 2014. "Penerapan Model Pembelajaran Conceptual Understanding Procedures Untuk Meningkatkan Curiosty Dan Pemahaman Konsep Siswa." Pendidikan Fisika Indonesia 10 (1).

Permendiknas. 2006. Tentang Standar Isi Pendidikan Dasar Dan Menengah. Jakarta.

Rahma, Yeni Wery. 2018. "Meningkatkan Pemahaman Konsep IPA Menggunakan Model Quantum Teaching Di Kelas 5 Sekolah Dasar." PGSD FKIP Universitas Jambi.

Rizkianingsih. 2012. "Pembelajaran Berbasis Masalah Dengan Pendekatan Inquiri Pada Pokok Bahasan Pemantulan Cahaya Kelas VIII MTS." UNNES Physics Educationd Journal 2 (3).

Rusmianto, Dhony. 2012. "Meningkatkan 
Keterampilan Menyimpulkan Melalui Metode Eksperimen Pada Mata Pelajaran IPA." PGSD FKIP Universitas Sebelas Maret.

Safitri. 2020. "Penerapan Model Conceptual Understanding Procedures Untuk Meningkatkan Kemampuan Pemahaman Konsep Matematis Siswa MTS." Al Khawarizmi: Jurnal Pendidikan Dan Pembelajaran Matematika 4 (1).

Siregar. 2016. "The Effectivitass Of Model Learning CUPs: Impact On The Higher Order Thinking Students at Madrasah Aliyah Mathala'ul Anwar Gistting Lampung." IImiah Pendidikan Fisika AlBiruni 5 (2).

Sugiyono. 2015. Metode Penelitian Pendidikan Pendekatan Kuantitatif, Kualitatif, Dan $R \& D$. Bandung: Alfabeta.

Suhendi. 2014. "Peningkatan Pemahaman Konsep Dan Profile Miskonsepsi Siswa Berdasarkan Hasil Diagnosis Menggunakan Pembelajaran ECIRR Berbantuan Simulasi Virtual Dengan Instrumen Tritiertes." Pendidikan Fisika Pascasarjana Universitas Pendidikan Indonesia Prosiding Matematis and Science Forum.

Suryanti. 2017. "Penerapan Metode Diskusi Untuk Meningkatkan Kognitif Siswa Kelas VII SMPN 7 Kuntodarusalam." Program Studi Pendidikan Biologi FKIP Universitas Riau.

Yani, Yanti. 2013. "Pembelajaran Kooperatif Fair Check Berpengaruh Terhadap Hasil Belajar Materi Bangun Ruang Dan Bangun Datar Siswa Kelas 4 Gugus 4 Semarapura." Jurusan Pendidikan Guru Sekolah Dasar, FIP Universitas Pendidikan Ganesha. 